Omni-Akuatika, 12 (2): 99-103, 2016
ISSN: 1858-3873 print / 2476-9347 online
Research Article

\title{
Growth Performance of Mono Sex and Mixed Sex Climbing Perch (Anabas testudineus)
}

\author{
Helmizuryani ${ }^{1, *}$, Boby Muslimin ${ }^{1}$ \\ Department of Aquaculture University of Muhammadiyah Palembang, Palembang, Indonesia
}

Received 20 June 2016; Accepted 15 October 2016; Available online 30 November 2016

\begin{abstract}
Many factors influence fish growth like rearing by sex. This study aims to determine the growth of the Climbing perch of the different sexes. This research was conducted at hatchery business unit at Mulya Plaju, from May to July 2015. Fry spawning fish came from the wet Laboratory Faculty of Agriculture, University of Muhammadiyah Palembang. They were maintained separately between the male and the female and the gender-mix between male and female, reared in nets with a density of 30 individuals each net; each treatment was repeated three times. During the research, fry feed used artificial feed with $30 \%$ protein compotition. The results showed that there was growth of female was faster than of male and of mixed sex. The growth of fish was $1,40 \mathrm{~cm}$ and weight of $4.56 \mathrm{gr}$, while survival rate of them was $100 \%$.
\end{abstract}

Keywords : growth, Anabas testudineus, mixed sex, mono sex

\section{Introduction}

Climbing perch (Anabas testudineus) is one of the native fish species Indonesia that spreads over several public waters on the island of Borneo, Sumatra, and Java. This fish is one type of resident fish (brackfishes) that generally lives wild in the waters of swamps, rivers and lakes. Demand for Climbing perch in South Sumatra is quite high, causing the price of Climbing perch to continue to rise. Climbing perch is favored by many people as the meat is good and tasty. However, it is not yet widely cultivated. In order to meet the demand for that fish, fishermen rely on catches from the wild season. Currently, this fish population declines because of overfishing. One effort which is needed to develop the fish farming is the provision of quality seed in adequate quantities and in the right time.

Our preliminary research on Climbing perch that showed that natural Climbing perch can be domesticated by improving gonad maturation etching of parent fish, Tubifex worm feeding and spawning of etching method by injecting the ovaprim. Moreover, The result indicated the fish seed etching can be maintained optimally with nursery in the tub; fish seed etching can adapt and evolve until physiologically well and the seeds could enlarge through the process of cultivation or acclimatization, proper maintenance to maintain fish seed etching through the stocking density, which was 30 fish per net, feed containing a mixture of maggot and pellet, and with a depth of $40 \mathrm{~cm}$. In the end, the result obtained was in the form of product quality fish seeds.

Nonetheless, once observed, there was a lack in optimizing the seeds to become preferred by the community; it was due to the absence of proper domestication in the maintenance of the Climbing perch as adultsize consumption is growing rapidly. It is necessary for the maintenance of a single sex as the community prefers consuming bigger fish.

\section{Material and Methode}

\section{Study Area}

Climbing perch were collected from Lebak Lebung, Komering River, Ogan Komering llir, South Sumatera.

\section{Procedures}

This research was conducted in the Hatchery Business Unit in Plaju for three months from May to July 2015. The materials used were: Seed of Climbing perch aged 90 days, 270 fish with weight of $2 \mathrm{~g}$ more or less, and a length of $3 \mathrm{~cm}$, the spawning result of wet lab study program at Aquaculture Faculty of Agriculture, University of Muhammadiyah Palembang. The feed was given in the form of commercial pellets containg $30 \%$ protein. This was given as much as two to three percents of the weight of the population, given in the morning, afternoon and evening. The tool used were nine units of nets measuring $50 \times 50 \times 75$ $\mathrm{cm}$ and were placed in a pool measuring $20 \times 8$ 
x $3 \mathrm{~m}$; $\mathrm{pH}$, thermometer, dissolved oxygen, and ammonia were also measured.

The study was conducted using completely randomized design method that was repeated three times. The treatments were: J1, the seed of Climbing perch with 30 male fish/ net; J2, the seed of Climbing perch with 30 female fish/ net; J3, the seed of Climbing perch with 30 mixed gender fish/ net.

The parameters observed were:

Life sustainability (Survival Rate, or SR) is the number of fish that are still alive after a certain time. The fish were observed daily for identifying the death among them and the result was recorded. Survival value was calculated using the formula (Effendi, 2004): The number of fish that are still alive/ The number of first fish $x 100 \%$

The weigth of fish was measured by calculating weight gain and length, by using the formula (Effendi, 2004): The final weight of fish (g) - Initial weight of fish (g), and Length gain: End length of fish $(\mathrm{cm})$ - Initial length of the fish (cm). Measurement of water quality included water temperature, $\mathrm{pH}$, dissolved oxygen, dissolved carbon dioxide levels; this was done every 10 days. Observation results were tabulated in Complete Randomized Design
Table, and analyzed using $F$ analysis. If the analysis results obtain $\mathrm{F}$ count $<\mathrm{F}$ table $(5 \%$ and $1 \%$ ), further tests are no need to be conducted, but if $\mathrm{F}$ count> $\mathrm{F}$ table, further tests must be conducted by involving coefficient of diversity. The average value of growth and survival of the fish will be displayed in the form of a histogram.

\section{Results and Discussion}

Survival Climbing perch fish of the opposite sex

Figure 1 shows the survival rate of fish etching with different sexes and the highest percentage was in $\mathrm{J} 2$ treatment (female fish) at $100 \%$ followed with $\mathrm{J} 1$ (male fish) by $95.55 \%$ and the lowest one was in J3 (mixed gender fish) amounting to $75.55 \%$. From the data obtained through subsequent calculation of variance analysis, it shows that the treatment toward the different sex fish had a significant effect on the survival rate (SR) of the Climbing perch. The same letter (b) means highly significant $(5 \%)$.

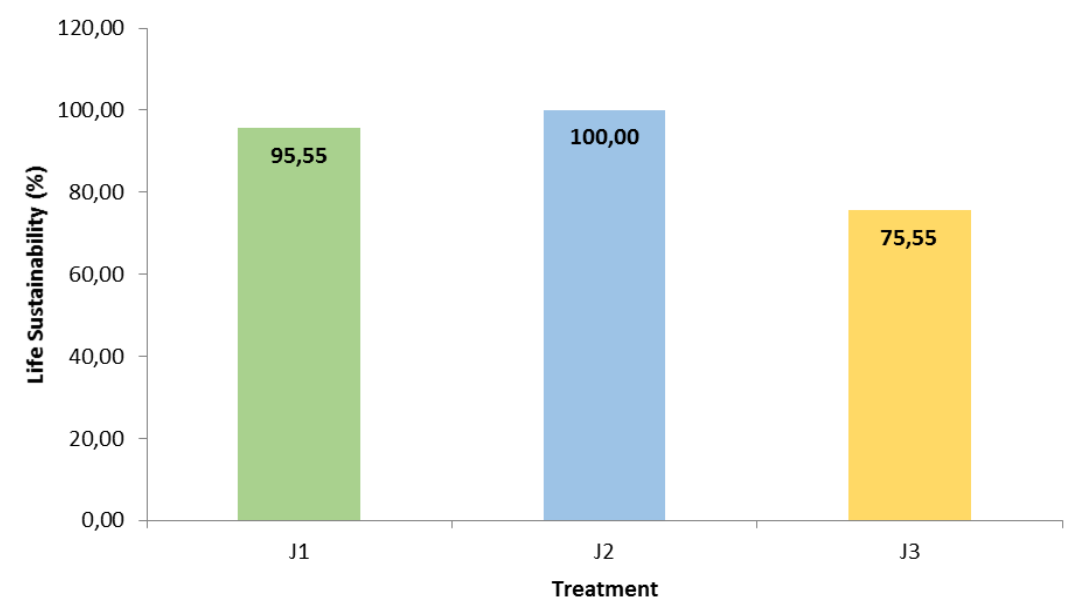

Fig. 1. Average rate of Life Sustainability of Climbing perch during the research 
Tab. 1. Test on the smallest significant differences of Climbing Perch

\begin{tabular}{ccc}
\hline Treatment & Average & LSD $_{0,05}=6,28$ \\
\hline J1 & 95,55 & $\mathrm{~b}$ \\
J2 & 100,00 & $\mathrm{~b}$ \\
J3 & 75,55 & $\mathrm{a}$
\end{tabular}

Based on Table 1 above, 5\% LSD test results showed that the $\mathrm{J} 2$ treatment had no significant effect to $\mathrm{J} 1$ but was significant to $\mathrm{J} 3$. The survival value of Climbing perch seed with different sex ranged from 75.55 to $100 \%$. The highest survival value was found in the J2 treatment of female fish by $100 \%$. All the treatments were above $50 \%$. The high survival value of the female was because female fish prefered to migrate from the bottom to the surface, and vice versa, while male fish prefered to be in the bottom. When the female fish were on the surface of the net, artificial feed which was supplied was directly consumed by fish seed etching, in addition to natural food as well. Furthermore, when the female fish moved to the bottom of net, remnants of feed that fell to the bottom of the net were also eaten by Climbing perch, in addition to the natural food form of benthos, which was also favored by the fish. Meanwhile, the lowest survival rate was in the mixed gender, between male and female, due to competition in fighting for food as each male and female fish was trying to get food. If available food was less than required, they would be cannibal. Then at the time of stocking fish of Climbing perch species between male and female, many could not survive or could not adapt with the new environment so that its survival rate was low.

The growth of length and weight of Climbing perch with different sexes

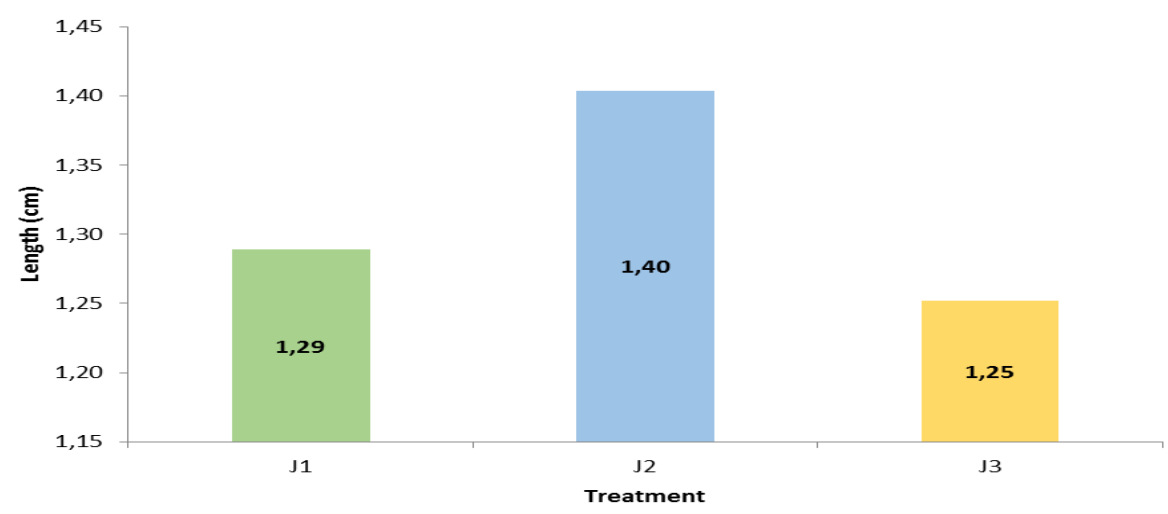

Fig. 2. Graph of the average length of Climbing perch growth during the research

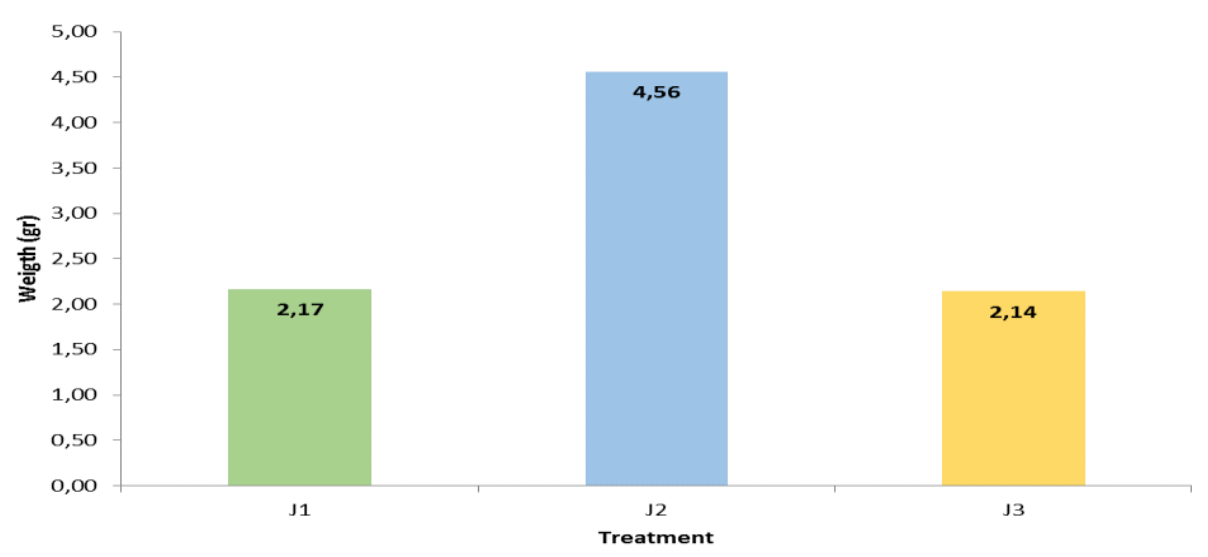

Fig. 3. Graph of the average weight of Climbing perch growth during the research 
Table 2. Test on the smallest significant differences of Climbing perch

\begin{tabular}{ccc}
\hline Treatment & Average & \\
& & BNT0,05 $=1,60$ \\
\hline$J_{1}$ & 2,17 & $\mathrm{a}$ \\
$J_{2}$ & 4,56 & $\mathrm{~b}$ \\
$\mathrm{~J}_{3}$ & 2,14 & $\mathrm{a}$ \\
\hline
\end{tabular}

Figure 2 shows that the highest lenght growth was in $\mathrm{J} 2$ treatment (female) with 1.40 $\mathrm{cm}$, while the lowest one was in the $\mathrm{J} 3$ (male and female) of $1.25 \mathrm{~cm}$. The diversity of the data analysis results shows that treatment with the opposite sex did not really affect the length growth of the Climbing perch, where $F$ count was smaller than $\mathrm{F}$ table $5 \%$.

Also Fig. 3 shows the biggest weight gain was in $\mathrm{J} 2$ treatment (female) with $4.56 \mathrm{~g}$, while the lowest one was in J3 (male and female) with $2.14 \mathrm{~g}$. From the data analysis results, it showed that the diversity in treatment of the different sex significantly affected the weight gain of the Climbing perch, where $\mathrm{F}$ count was larger than $\mathrm{F}$ table $5 \%$. The same letter means very significant $(5 \%)$.

Based on Table 2, the results of 5\% LSD indicate that $\mathrm{J} 2$ treatment had a significant effect on $\mathrm{J} 1$ and $\mathrm{J} 3$ treatments.From the observations that have been made, the study of water quality was still feasible for the life of the seeds that were maintained. From the research of growth of mixed gender Climbing perch fish, on the seed, the highest length and weight growth was in $\mathrm{J} 2$ treatment, amounting to 1.40 $\mathrm{cm}$ lenght and $4.56 \mathrm{~g}$ weight for female. Female Climbing perch grew faster than males because female Climbing perch were more active either in eating eat the feed or in swimming from the bottom to the surface in addition to the quality of the water supports. Natural food was spread on the surface to settle to the bottom of the water, so the natural food at the bottom of a pool / net could be eaten by the female fish on the surface and the artificial feed was also eaten by the female fish. The results of this study according to Kocour et al., (2003) who conducted research on goldfish that showed that carps which were kept in population of female fish grew faster than the mix (malefemale), and carps which were maintained with one type of gender would have faster growth (Wohlfarth et al., 1975 in Kocour et al., 2003). The lowest value was found in $\mathrm{J} 3$ treatment with $1.25 \mathrm{~cm}$ for the length and $2.14 \mathrm{~g}$ for the weight of the male and female fish. The male and female Climbing perch competed in eating feed, thus the growth for each fish was slow. It was also caused by environmental conditions, which were less supportive for fish to grow and even caused the fish to become stressed. This is in line with the opinion from (Wedemeyer, 1996 in priyadi et al., 2010) that health issues and chronic stress are the results of social dominance of fish that are found in the interaction between the fish and are common in an intensive culture system, where the fish are subordinate (weak) and have very little access to take food and tend to grow more slowly; this is because of the caloric energy produced slightly as a result of a chronic stress condition. In the chronic condition, fish tend to be slow growing because they use more energy to survive rather than to grow.

Fish will be able to grow optimally if maintained properly by differentiating the gender (Kocour et al., 2003). There are several species of fish that have the capability for optimal growth with such distinction, such as tilapia (Oreochromis nilocticus), in which male tilapia will grow faster than the female tilapia due to the ability to grow physically (Schreiber, et al., 2007). Things that make male tilapia grow faster are such as anabolism of the effects of androgen hormone, genotype, the quantity and quality of feed, stock management, and environment. Moreover, male tilapia have hyperphagia (high appetite) because they do not spend energy on reproduction (Bareeto et al., 2003; Dagne et al., 2013). In addition to tilapia, common carp (Cyprinus carpio L.) is also fish whose growth rate is affected by gender. Special care to the female fish has a positive effect on growth when compared to pisciculture as bisexual (mixed male and female) (Kocour et al., 2003). Unisexual female tilapia also have the ability to grow faster than the male tilapia when reared individually. This is because the female fish are able to perform with good energy retention; it relates to the habit of female fish in storing food, especially to perform mouth-breeding (hatch and giving the intake of fish larvae in the mouth) that shows a low rate of fish metabolism and oxygen consumption rate. There are several things that affect the growth of male and female tilapia, namely physiological factors, environmental, 
and genetic factors (Schreiber, et al., 2007). In this study, female Climbing perch fish had a larger size compared with that of the male. This was because female Climbing perch fish was better in preparing for reproductive activity, especially in May (Alam et al., 2010). It is one of the habits of the Climbing perch in the face of time prior to mating, which contrasts with female tilapia that reduce feeding, especially during the mouth-brooding (Schreiber et al., 2007). During the growth period of the Climbing perch, the most influential factor is feed; feed with the right content and appropriate level of protein, such as pellets with $50.92 \%$ protein, will cause fish etching to be optimal compared to $30 \%$ and $20 \%$ protein of pellets (Alam et al., 2010). In this study, fish etching was given feed with 30\% protein for Climbing perch fish maintained in a net for only a single sex. The results on female fish show that they had optimal growth compared to the male fish that were kept in one net or mixture. Thus, the Climbing perch fish growth capability would be optimum with mono-sex maintenance, but it still needs further research for pisciculture of monosex etching accompanied by other factors that affect growth.

\section{Water Quality}

From the observations (table 3 ) which have been conducted during the study, it shows that the temperature ranged from 27.0 to 30.0 ${ }^{0} \mathrm{C}$; $\mathrm{pH}$ ranged from 7.2 to 8.2 , dissolved oxygen 7.20 to $8.96 \mathrm{mgl}^{-1}$; and ammonia ranged from 0.0485 to $0.0562 \mathrm{mgl}^{-1}$. The water quality during the study was still feasible for the life of the seeds which were kept.

\section{Conclusion}

From the research that has been done, several things can be concluded as follows: Fish survival etching with different sex was highest in $\mathrm{J} 2$ treatment (female fish) by $100 \%$ and the lowest one was in $\mathrm{J} 3$ treatment (male and female) by $75.55 \%$. The highest length growth was found in $\mathrm{J} 2$ treatment (female) amounting to $1.40 \mathrm{~cm}$, while the lowest one was in $\mathrm{J} 3$ (male) with $1.25 \mathrm{~cm}$ and weight growth was the highest in $\mathrm{J} 2$ treatment (female) with $4.56 \mathrm{~g}$, while the lowest was in $\mathrm{J} 3$ treatment (male and female) with $2.14 \mathrm{~g}$.

\section{Acknowledgment}

The writer would like to thank the Directorate General of Higher Education that has funded this study, to all reviewers of this paper; Prof. Dr. Siti Herlinda, M.Si. from Biological Control, University of Sriwijaya
(UNSRI), Palembang, South Sumatera; Dr. Ir. A.D. Murtrado, MP. for the Manuscript peer reviewer, and Dean at Agriculture Faculty, University of Muhammadiyah Palembang (UM Palembang); all participants of Research Institute for Inland Fisheries (RIIF), Palembang, South Sumatera); Prof Dr. Diah Natalisa, M.B.A. as the Chairman of Kopertis Region 2, South Sumatera, and Dr. H.M. Idris as Rector of the University of Muhammadiyah Palembang that has permitted this research, the Head of the Institute for Research and Service at Community of Muhammadiyah Palembang University who facilitated this research, all lecturers, and undergraduate students of Aquaculture Program, UM Palembang for the great guidance, valuable input, and support until the completion of this study, and all parties who have helped in this research

\section{References}

Alam, J., Mustafa, G., Islam, M. 2010. "Effects of some artificial diets on the growth performance, survival rate and biomass of the fry of Climbing perch, Anabas". Journal of Nature and Sciene 8 (2): 36-42.

Barreto, R.E., Moreira, P.S.A., Carvalho, R.F. 2003. "Sex-specific compensatory growth in food-deprived nile tilapia". Journal of Medical and Biological Research 36: 477-483.

Dagne, A., Degefu. F., Lakew, A. 2013. "Comparative growth Performance of Mono-Sex and Mixed-Sex Nile Tilapia (Oreochromis niloticus L.) in Pond Culture System at Sebeta, Ethiopian". International Journal of Aquaculture 3 (7): 30-34.

Effendi, I. 2004. Pengantar Akuakultur. Penerbit Swadaya. Jakarta.

Kocour, M., Linhart, O., Gela, D., 2003. "Results of comporative growing test of all-female and bisexual population in two-year-old common carp (Cyprinus carpio L.)". Journal of Aquaculture International 11 (4): 369378.

Priyadi, A., Ginanjar, R., Permana, A., Slembrouck, J. 2010 . "Tingkat macracnthus) dalam Satuan Volume Air pada Akuarium Sistem Resirkulasi". Prosiding Forum Inovasi Teknologi Akuakultur. 439-446.

Schreiber, S., Focken. U., Becker, K. 2007. "Individually reared female Nile tilapia (Oreochromis nilocticus) can grow faster than the males" Journal of Applied Ichtiology 4: 43-47. 